\title{
Introductory article for Special issue: Conceptions of early childhood and institutions in a global context
}

\author{
ORSOLYA ENDRŐDY ${ }^{1 *}$ (1), BAHBIBI RAHMATULLAH ${ }^{2}$ and \\ ISTVÁN LÉNÁRT ${ }^{3}$ [1]
}

\author{
${ }^{1}$ Faculty of Pedagogy and Psychology, Eötvös Loránd University, Budapest, Hungary \\ ${ }^{2}$ Data Intelligence and Knowledge Management (DILIGENT), Faculty of Arts, Computing and Creative \\ Industry, Sultan Idris Education University, Malaysia \\ ${ }^{3}$ Institute of Linguistics and Intercultural Communication, Sechenov University, Moscow, Russia
}

\section{THEMATIC ARTICLE}

Received: June 30, 2021 - Accepted: August 30, 2021

Published online: November 29, 2021

(C) 2021 The Author(s)

\begin{abstract}
The recognition of the importance of early childhood education (ECE) has been growing continuously in recent years. Early childhood institutions are where professional pedagogy and child-rearing practices meet first in someones' life (Tobin et al., 2009), it has great significance in education. Acknowledgement of the existence of the needs of young children's education is evident, however, we have limited chances to compare different education systems outside of Europe and the United States. Realizing this situation, we came to the conclusion that it is highly necessary and required to publish such an analytical issue in the Hungarian Education Research Journal. Teacher's views and their narratives of childhood are relevant if we aim to understand the fundamental differences of ECE institutions in any region or country. In our present investigation we collected data from Hungary, Laos and Malaysia in order to acquire greater knowledge on the conceptions of early childhood in the three countries. We assumed however that the teachers' qualification and the early childcare system is diverse, yet we have found similarities among the teachers' perception.
\end{abstract}

\section{KEYWORDS}

early childhood education, childhood, comparative analysis, qualitative

\footnotetext{
*Corresponding author. E-mail: endrody.orsolya@ppk.elte.hu
} 


\section{OBJECTIVES OF THE ISSUE AND PRESENT RESEARCH}

When the present issue had been decided, the aims were to collect data and analysis from early childhood teachers to deepen understanding and knowledge about various kinds of conceptions of childhood with a special focus on early years. We believe that we can understand differences in the policies of ECE if we aim to collect analytical introductions of different education systems outside of Europe and the United States.

Present research focuses on three countries: Hungary, Laos, and Malaysia and their early childcare system as a scaffold, with a special interest toward the in-service teachers' views on the importance and narrative of early childhood.

\section{The genesis of the study}

This research emerged from a series of discussions on the main topic of this issue, the lack of knowledge of ECE in a global and postcolonial context and a vast deficit of studies about nonwestern countries' early year's program published outside their region.

\section{The importance of interdisciplinary collaboration}

Interdisciplinary collaboration could enhance researchers creativity, and researchers can inspire each other as well as compare and measure data with relevant tools. We opine that an interdisciplinary examination such as the present one would make the examination valid. A vast amount of literature examines these kinds of researchers collaborations. We can see that in the past decade - collaborations between researchers across academic disciplines has risen - from every corner of academic fields, we may find examples. As Frickel, Albert, Prainsack, mentions $(2017,5$.$) , interdisciplinary$ research generates more robust understandings of the social world than knowledge emerging from a single traditional discipline only. In this study, the authors merged the perspective of ECE studies with a linguistic approach, the word association method detailed in the Method chapter.

\section{THEORETICAL CONSIDERATIONS}

\section{Teachers' view within early childhood settings}

The development of a child is dynamic and impacted by their relationships, surroundings, and experiences. Teachers in early childhood education are often a young child's first point of contact with the educational system, and how teachers perceive the child and early childhood education influences how they interact and form relationships. Learning is an active process that is situated inside local practices and differs from one community to the other (Lave \& Wenger, 1991).

Values, beliefs, conceptions, expectancies, and perceptions are all part of the overall construct of views or ideas. It is also known as mental representations, and it refers to mental constructs of experience (Sigel, McGillicuddy-DeLisi, \& Goodnow, 2014). Teachers' views have ramifications in terms of teaching and decision-making, and hence may aid understanding of classroom practises (Fives \& Buehl, 2012; Patterson, Doppen, \& Misco, 2012). Wood (2014), for example, asserts that activities with children in the classroom are always influenced by teacher beliefs and the value and meaning teachers assign to the activity (such as play), curriculum, policy, and 
classroom order, goals, and regulations. According to Correia, Camilo, Aguiar, and Amaro (2019), studies on ECE teachers' beliefs and views about children's participation may provide important insights into the conditions required to promote participation in the classroom.

Teachers' views are permeable to the cultural values of the society or groups to which they belong. It is thus important to conduct research in countries with distinct cultural characteristics, such as those in southern Europe and Asia. With the increasing global emphasis on improving provision for supporting children's ongoing learning and growth (OECD, 2019), a cross-national investigation into the perspectives of early childhood teachers from different regions and social cultures are timely.

\section{Narratives of childhood and children as social actors}

We certainly thank Ariés (1960), whom we see as the founder of the field of childhood studies; however, he examined a limited amount of sources and periods. A group of British sociologists such as Jenks (1982), James and Prout (1990) created a new paradigm. They suggest examining childhood as a social construction. This idea is widely recognized and accepted, followed by most scholars of the field. As Jenks summarizes the theory, childhood is a variable of social analysis. Different narratives can be made based on ethical, class or gender perspectives. There are varieties of childhood, and it is not a universal phenomenon (Jenks, 2015). In this paper, we suggest adding the cultural layer to these distinctions. Narrative means that depending on the analyzed source, we are able to construct the possible definition of childhood valid on the examined data.

We should add that children are not passive subjects (Jenks, 2015) of the analysis, but they are able to determine their own life; in that case, they should be seen as social actors (Hendrick, 2000).

\section{INTRODUCTION OF THE EARLY CHILDHOOD CARE SYSTEM}

\section{Early childhood care system in Laos}

The Lao People's Democratic Republic is a relatively small, landlocked country with a population of 7.2 million (World Bank, 2019). The country which can be characterized by a one-party socialist system since the end of the Vietnam war in 1975, is situated on the Indochinese Peninsula and is bordered by Vietnam, China, Thailand, Myanmar, and Cambodia. Laos is led by the Lao People's Revolutionary Party and belongs to the group of least developed countries of the world. The GDP per capita reached 2,530 USD per annum in 2019 (World Bank, 2019).

The Ministry of Education and Sports oversees the Lao education system, and preschools are under the guidance of its Department of Pre-school Education (DPE). Since 1975, the education sector has followed the Lao vision of "education for all" principle (Noonan, 2014), incorporating two endeavours of crucial importance including 1.) inclusiveness (inclusion, regardless of gender, ethnicity, language, etc.), and 2.) continuity (lifelong learning). The country's achievement in this regard is remarkable: the primary school enrolment rate increased from 58\% in 1992 (World Bank, 2019) to 98\% in 2015 (Lachanthaboun, 2015).

Regarding Early Childhood Education (ECE), the country is still facing considerable challenges. The enrolment rate of 3-5-year-old children in the ECE system remains at a modest 43\% 
level due to various reasons, including poor infrastructure, food insecurity, low wages and insufficient qualification of preschool teachers, relatively high indirect costs of ECE, etc. (Lachanthaboun, 2015). In line with the government's pursuit to improve ECE in the Lao PDR, the Education and Sports Sector Development Plan (2016-2020) sets the objective "to provide the opportunity for children to learn Lao language and have readiness to study in primary education focusing on reducing drop-out and repetition of primary education." (Lachanthaboun, 2015:45). The objective is operationalized in two main targets, the first being the increase of the enrolment rate of 3-5-year-old children to preschools, followed by the second objective to provide sanitation facilities to all kindergartens.

Another foundational document regulating Early Childhood Education in Laos is the National Education System Reform Strategy (NESRS, 2006-2015) and its third chapter Preschool and Primary Education (Somsanith and Noonan, 2020). The NESRS specifies objectives for ECE, including 1.) improving the curricula, content, and methodology of pre-service teacher education to enhance the early development of children in terms of physical, cognitive, and aesthetic development, creativity, and speaking; 2.) expanding the network of model nurseries and kindergartens, especially in rural and remote areas, and to mobilize communities to build nurseries and kindergartens.

Finally, we could not agree more with the statement that "[the Lao] educational system is a product of the heritage of colonialism, socialist revolution, and the movement towards a market economy and privatization" (MacKinnon \& Thepphasoulithone, 2014: 21), adding that seemingly the last two latter of the three mentioned aspects gained substantially much emphasis in the last two or three decades. Thus, the strong central, governmental guidance of ECE and the government-run preschools with relatively modest enrolment rates are gradually complemented by rather costly private kindergartens that a thin layer of society can afford.

\section{Early childhood care system in Malaysia}

In Malaysia, the early childhood programs are mainly divided into childcare centres (also known as nurseries or Taska for children from birth to four years old) and kindergarten (also known as preschools or Tadika for children aged $4+$ to $5+$ ). The former is regulated by the Department of Social Welfare under the Ministry of Women, Family and Community Development, while the latter is bound by the Education Act of 1996 overseen by the Ministry of Education. Each program has its own national curriculum specifically developed for each level, namely PERMATA National Curriculum for nursery level and National Preschool Standard Curriculum for kindergarten level.

Nursery or childcare centres in Malaysia are classified into community childcare centres, workplace childcare centres, institution-based childcare centres and home-based childcare centres. The establishment differs in terms of assistance from the Federal or State Government, incentives for furnishing and renovation if set up within government offices, tax incentives to employers for providing welfare services to their employees, number of children under care and premise of operations. Home-based centres with less than four children are currently not required to be formally registered.

Kindergartens are operated by various government agencies, such as the Ministry of Education, Ministry of Rural and Regional Development, Ministry of National Unity, and other state-level agencies. These are part of the government's initiatives in making early childhood 
programs more accessible to children from low-income backgrounds and for those living in rural areas.

Kindergartens operated by private sectors also exist to complement the government's efforts. These kindergartens would need to adhere to the National Preschool Curriculum as stipulated by the 1996 National Education Act. However, some of these kindergartens also offer "imported models" and commercialized child learning programs that are expensive and accommodate working parents' convenience (Majzub \& Rashid, 2012; Qin \& Nor, 2018).

Six key areas of learning and development emphasized in the national curriculum for nursery level include; i) development of early mathematics and logic thinking, ii) development of senses and understanding of the environment, iii) development of language, communication and early literacy, iv) development of creativity and aesthetics, v) physical development, and, vi) personality, socio-emotional and spiritual development (Bahagian PERMATA, 2013).

The content of the national curriculum for kindergarten level, which was introduced in 2010 and was later revised in 2016 in tandem with the Malaysia Education Blueprint 2013-2025 and current educational needs, revolves around these six aspects, namely: i) communication, ii) science and technology, iii) spiritual, attitude, and values, iv) humanity, v) self-appearance and, vi) physical and aesthetic development. Preschool education aims to nurture children's potential in a comprehensive manner across all the stated aspects in a safe and conducive learning environment through fun, creative, and meaningful activities. This is in line with the National Education Philosophy, which aims to produce holistic individuals to advance society and the country (Kementerian Pendidikan Malaysia, 2013).

\section{Early childhood care system in Hungary}

In Hungary, it is compulsory to attend kindergarten from the age of 3 (ISCED 0). Exceptions can be given by a Body of the Government based on the family circumstances, special development of the child or her/his particular situation. In such cases, he/she must start compulsory kindergarten at the age of 4 . The child must spend $4-12 \mathrm{~h}$ daily in kindergarten (Euridyce, 2021). There are public and private kindergartens: the previous ones are maintained by municipalities, sometimes state universities. The private ones could be owned by anybody, like NGOs, churches, non-state Higher Educational Institutes, companies or private people (Rónay 2019) and fees apply to parents. According to the OECD country report, 79\% of the age group population attended pre-primary institutions in 2016 (OECD, 2016), just after the declaration of compulsory attendance in 2015. According to the Central Statistic Office, the attendance ratio rose to $92,1 \%$ by 2020 (KSH, 2021).

Public kindergarten is free; however additional fees are applicable, such as fee for meals or additional services.

Kindergarten teachers needed a BA qualification to enrol or fill a position; however, the lack of pre-primary teachers is increasing. Teachers have a relatively low salary with $40 \mathrm{~h}$ of weekly work compared to other EU member countries' teachers' salaries (OECD, 2016).

There are two kinds of institutions for ECEC one is called bölcsöde - nursery or creche available from 20 weeks old to 3, and óvoda - kindergarten that children can attend from 3 to 6 . When the child becomes six by August 31, it is a must to attend the elementary. Exceptions can be given to SEN children or those whom an Official Pedagogical Counsellor approves. In such cases, the child can attend school for one more year. 
Both institutions - creche and kindergarten - are overseen by the Ministry of Human Capacities but under different secretariats because only the kindergarten is part of the public education system (Euridyce, 2021).

Based on the Basic Program for Kindergarten Education, "the aim of kindergarten education is to promote the multifaceted, harmonious development of children, the development of children's personalities, the mitigation of disadvantages, considering the age, the individual characteristics, as well as the different developmental space of children (including care for children with special needs)" (Euridyce, 2021; ÓNOAP, 2012).

\section{RESEARCH APPROACH}

\section{Sampling and description of study participants}

Researchers collected the data on the field in their respective countries of residence. The survey was completed with 100 kindergarten and/or nursery teachers from each country (300 respondents in total). Participants were interviewed in all three countries via an online questionnaire generated in four languages (Hungarian, English, Lao, Malaysian). The analysis of the participants' demographic information given in terms of percentage is depicted in Table 1 . The original questionnaire was compiled in English then translated to the above-mentioned further three languages. In the course of the translation process, researchers thrived on finding the wording of the most similar denotation when compared to the English original.

\section{Method}

Previous researches including the following ones are also focusing on the teacher's childhood narratives (Aggné Pirka \& Endrődy-Nagy, 2015; 2017a, b; Endrődy, 2013; Herz, 2016; Serföző \& Böddi, 2018; Trentinné, 2013, 2015). However, those are not comparing data from other countries focusing on the Hungarian data only. Using the following pattern: child/teacher/ kindergarten is like something, we usually expect respondents to answer with the first thought that comes into their mind, which is usually a metaphor. Metaphors can help us to understand the deeper meaning regarding their narratives on the questioned stimuli. In our previous investigations, we focused on $4 / 5$ years olds and 10/12 years olds narratives with a similar method; however, with the younger ones, we did an on-site survey during their free playtime (Endrödy, Imai, \& Lénárt, 2019; Endrody, Lenart, \& Markovina, 2020).

As an underlying research method - besides questions about the ECCE system - word associations were collected from the respondents in connection with three stimuli, including a child, a kindergarten teacher, and a kindergarten. The association method is a widely applied scientific research method used in psychology/psychiatry for more than a century (Kent \& Rosanoff, 1910), later in psychology and linguistics (Kiss, Armstrong, Milroy, \& Piper, 1973; Moss, Older 1996; Palermo \& Jenkins, 1964; Postman \& Keppel, 1970), and proved to be a pivotal methodologic foundation of the Moscow School of Thought of Psycholinguistics (Lénárt, 2017; Tarasov, 1996; Ufimtseva, 2014). Utilizing the association method, linguists and interculturalists aim at gaining a clearer picture of the mental lexicon of the individual by scanning word associations given to preselected stimulus words.

We analyzed the frequency of the associations and created the codes based on the similar meanings of the source domain. For example, whiteness and purity have similar meanings 
Table 1. Demographic information by the percentage of participants per country (\%)

\begin{tabular}{|c|c|c|c|}
\hline & Hungary & Laos & Malaysia \\
\hline \multicolumn{4}{|l|}{ Gender } \\
\hline Male & 0.00 & 0.00 & 4.00 \\
\hline Female & 100.00 & 100.00 & 96.00 \\
\hline \multicolumn{4}{|l|}{ Age (Years) } \\
\hline$<20$ & 0.00 & 0.00 & 12.00 \\
\hline $21-30$ & 17.00 & 54.00 & 40.00 \\
\hline $31-40$ & 11.00 & 46.00 & 30.00 \\
\hline $41-50$ & 35.00 & 0.00 & 16.00 \\
\hline$>50$ & 37.00 & 0.00 & 2.00 \\
\hline \multicolumn{4}{|l|}{ Mother tongue } \\
\hline English & 0.00 & 2.00 & 82.00 \\
\hline Malay & 0.00 & 0.00 & 18.00 \\
\hline Chinese dialect & 0.00 & 0.00 & 2.00 \\
\hline Lao & 0.00 & 98.00 & 0.00 \\
\hline Hungarian & 100.00 & 0.00 & 0.00 \\
\hline \multicolumn{4}{|l|}{ Workplace } \\
\hline Nursery & 0.00 & 8.00 & 32.00 \\
\hline Kindergarten & 95.00 & 82.00 & 50.00 \\
\hline Home childcare & 1.00 & 6.00 & 16.00 \\
\hline Transit day & 0.00 & 0.00 & 2.00 \\
\hline Counselling office & 3.00 & 0.00 & 0.00 \\
\hline Day care & 1.00 & 1.00 & 0.00 \\
\hline Other & 0.00 & 3.00 & 0.00 \\
\hline \multicolumn{4}{|c|}{ Minimum qualifications needed to fill in the position } \\
\hline None needed & 0.00 & 1.00 & 22.00 \\
\hline Short term training & 0.00 & 38.00 & 4.00 \\
\hline High School Certificate/Diploma & 2.00 & 35.00 & 40.00 \\
\hline Tertiary Diploma & 0.00 & 0.00 & 34.00 \\
\hline Bachelor degree & 79.00 & 15.00 & 0.00 \\
\hline Master degree & 5.00 & 7.00 & 0.00 \\
\hline Others & 14.00 & 4.00 & 22.00 \\
\hline
\end{tabular}

regarding the cleanliness, innocence of the child. Little animals might also make a category regardless of their type, e.g. calf, kitten, bear cubs etc. Plants, seeds might also need gardening in order to start growing.

\section{ANALYSIS}

\section{Word associations from 100 respondents in Laos}

Reaction words to the quasi-association experiment that was conducted in the form of a sentence completion task (e.g., "Please continue the sentence. A child is like a/an...") are displayed

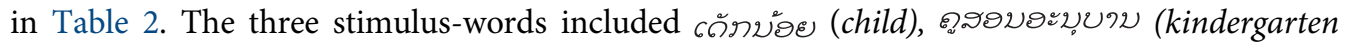
teacher), and โธรรรบงะบุบข (kindergarten). 
Table 2. Word associations with frequency based on sentence completion task, Lao respondents

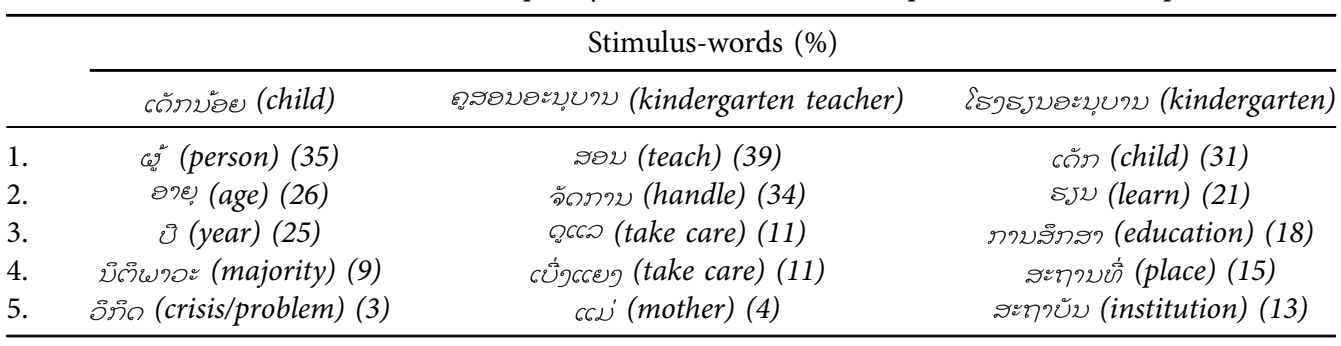

It is important to note that the etymology of the stimulus words presumably influences the selection and the frequency of the reaction words. Thus, it seems both logical and relevant to examine the three stimulus words one by one. The most evident and widespread equivalent of the Hungarian word gyerek (child) is сمัภขอย in the Lao language with a literal meaning: small child. Lao language users furthermore typically use its synonyms including ஓЛ (kid, child) and ชว

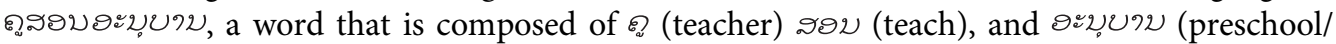
kindergarten). Finally, โธรรรมฮะขุบข is a word or phraseological unit (in the Lao language, it is difficult to differentiate between compound words, syntagms and phrases in the lack of division of syntactic units (no space is used in the written Lao language). Nevertheless, the syntactic composition of the word is transparent, and it contains the following units: [S (classifier word for buildings, factories, etc.) รృ๊ (learn), and ฮะบุขอ (preschool, also meaning protect/take care of).

The most frequent reaction to cลัวขอย (child) is $\operatorname{sg}^{2}$, a word that can be considered as a

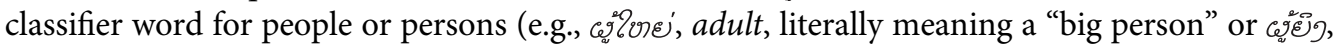
woman, literally meaning "female person"). The second, third, and fourth most typical reaction

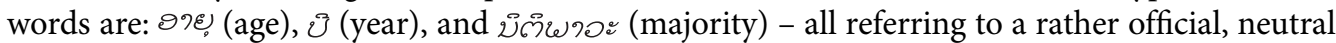
description of a child by referring to his/her age ("under 18 years of age") and to the fact that he/ she has not reached the age limit of majority. Lao respondents mentioned the word כூo (problem, crisis) in a context that a child is typically not able to solve issues/problems/crises individually.

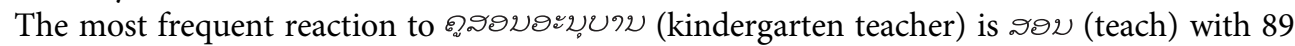
occurrences which can be at least partly explained by the fact that the stimulus word itself contains this syntactic element. The following three most typical reactions are all verbs referring to kindergarten teachers' activities. These verbs all denote a very similar activity: จัดภาบ (handle,

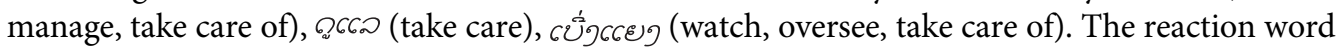
${ }_{c} \nu^{\prime}$ (mother) is also frequently evoked in the sense that the kindergarten teacher is similar to a second mother and complements the mother's activities.

The stimulus-word โธรรรปอะขูบขอ (kindergarten/preschool) evokes the noun cลัก (child, with 84 mentions) and the verb 5.J (learn, with 57 occurrences). These reactions - similarly to the reactions to the stimulus сดัวบอย (child) - are followed by references to a rather neutral, nearly scientific description of a kindergarten embodied in such lexemes as ภาบฐ็กรๆ (education), ระทาขยิ่ (place), and ระทาบัม (institution). 


\section{Word associations from 100 respondents in Malaysia}

Reaction words to the quasi-association experiment with the Malaysian respondents that was conducted in the form of a sentence completion task (e.g., "Please continue the sentence. A child is like a/an...") are displayed in Table 3. The three stimulus words included kanak-kanak (child), pendidik (nursery/kindergarten teacher), and taska/tadika (nursery/kindergarten).

In the Malaysian language, child or children is commonly translated as kanak-kanak. In the context of the Malaysian early childhood setting (which covers from birth up to preschool), there are two major settings of institutions which are nursery (commonly known as taska) and kindergarten/preschool (commonly known as tadika). So both words are combined in the sentence completion task prompt question as taska/tadika (nursery/kindergarten). As for the term teacher, there are many relevant terms in the Malaysian early childhood setting, including pendidik, pengasuh, guru and cikgu depending on the type and setting of the institution, which is either nursery (known as taska) or kindergarten (known as tadika), home-based, school-based or community-based. Hence, the term pendidik Taska/Tadika, which is composed of pendidik (teacher) and Taska/Tadika (nursery/kindergarten) is chosen, as it could be widely understood and accepted by many types of ECCE institutions.

The most frequent reaction to kanak-kanak (child) is kain putih (white cloth), which is a common metaphor taken from the Islamic prophetic tradition that mentioned that "A newly born child is like a piece of white cloth waiting to be patterned by his parents". It is also described in the second most frequent reaction word, which is suci (pure or innocent). The third, most typical reaction word is angel, which is entirely from English speaking respondents. It refers to the angelic characteristics of purity possessed by angels. However, angel (which is directly translated as malaikat in the Malay language) was never used by any Malay-speaking respondents because malaikat would also be interpreted as heavenly creatures (such as archangel) with special tasks according to religious texts and never used to describe a child. Bunga (flower) is the fourth most frequent reaction word, a metaphor for beauty and the need for touch, love, and care. Finally, 5\% occurrences of nakal ('cheeky' kind of naughtiness) are the fifth most recurring word used to describe a child.

Pendidik taska/tadika (nursery/kindergarten teacher) is commonly associated with the characteristics possessed by the teacher, which is penyayang (loving), with $21 \%$ of occurrences among the respondents. The second most typical reaction is ibu (mother), denoting the motherly characteristics of the teacher. (Female) teachers are also commonly perceived as mothers to their students in Malay cultures, where parents are perceived to have delegated the

Table 3. Word associations with frequency based on sentence completion task, Malaysian respondents

\begin{tabular}{|c|c|c|c|}
\hline & \multicolumn{3}{|c|}{ Stimulus-words (\%) } \\
\hline & Kanak-kanak (child) & $\begin{array}{c}\text { Pendidik (nursery/kindergarten } \\
\text { teacher) }\end{array}$ & $\begin{array}{c}\text { Taska/Tadika (nursery/ } \\
\text { kindergarten) }\end{array}$ \\
\hline 1. & kain putih (white cloth) (28) & penyayang (loving) (21) & belajar (learning) (16) \\
\hline 2. & suci (pure) (18) & ibu (mother) (18) & menyeronokkan (fun) (13) \\
\hline 3. & angel (8) & baik hati (kind) (9) & taman bunga (garden (7) \\
\hline 4. & bunga (flower) (8) & bijak (wise) (8) & bermain (play) (6) \\
\hline 5. & nakal (cheeky) (5) & lilin (candle) (5) & rumah (home) (6) \\
\hline
\end{tabular}


responsibility of nurturing and upbringing the child to the teacher. At the same time, they are sent for care and education at the school/nursery/kindergarten. The thirds and fourth most common reactions are penyayang (kind) and bijak (wise), which refers to the characteristics assumed by the teacher. The fifth most common reaction is lilin (candle), which is a metaphor for a person sacrificing themselves to provide their best service to other people.

The stimulus-word taska/tadika (nursery/kindergarten) evokes the verb belajar (learn, with $16 \%$ occurrences). It is also associated with menyeronokkan (enjoyable), an adjective that appears as the second most frequent reaction. The next most frequent reaction, which accounts for $7 \%$ of occurrences, is taman bunga (flower garden), a metaphor for beauty and a pleasant place for the children. Finally, bermain (playing) occurred $6 \%$ of the time, denoting the activity that takes place in the nursery/kindergarten. Nursery/kindergarten is also regarded as rumah (home), evoking the comfortable feeling that is perceived or trying to be achieved by the early childhood care and education providers (Table 3 ).

\section{Word associations from 100 respondents in Hungary}

Regarding the three stimulus-words we asked our respondents to react, the answer frequencies were analyzed and shown in Table 4.

Hungarian respondents seem to recognize children as flowers (19\%) or other plants, such as seeds, buds, or trees (16\%). Some of the respondents explain why they have answered and chosen from flora. For example, a child is like a little tree or a little foal. "Just like with trees, a child needs to be trained, taken care of, in order to develop her/his personality, talence; if he/she is slower than the others or lacks something, the caregiver needs to help, to correct him/her. We should compare her/him to her-/himself only, in order to cope with anything in the future." Another respondents mention that: "tomatoes and walnuts are different, different plants need different care, as well as children. They need to be treated differently."

There is a beautiful metaphor chosen by $14 \%$ of the Hungarian respondents. A child is like a treasure or an uncut, undone diamond. Some explain why he/she chose this association: "we must polish a diamond constantly, to be valued and beautiful!

"A clean sheet of paper, on what we can scribe, carve or dye. The quality of the sheet of paper (thin, adsorbent, easily ruptured, cardboard etc.) depends on the environment." Another one mentioned that: "we should not smear it."

Table 4. Word associations with frequency based on sentence completion task, Hungarian respondents

\begin{tabular}{lccc}
\hline & \multicolumn{3}{c}{ Stimulus-words (\%) } \\
\cline { 2 - 4 } & gyermek (child) & óvodapedaógus (kindergarten & \\
teacher) & óvoda (kindergarten) \\
\hline 1. & virág (flower) (19) & anya (mother) (29) & család (family) (31) \\
fa, mag, növény & kertész (gardener) (25) & kert (garden) (18) \\
& (tree, seed, plant) (16) & & \\
3. & kincs, csiszolatlan gyémánt (treasure, & polihisztor (polihistor) (17) & varázslatos hely \\
& undone diamond) (14) & & (magical place) (16) \\
4. & tiszta lap (clean paper) (9) & támasz (take care) (13) & otthon (home) (15) \\
5. & tükör (mirror) (9) & varázsló (wizard) (6) & fészek (nest) (9) \\
\hline
\end{tabular}


The most frequent mention among associations for a kindergarten teacher is a mother (anya) among Hungarian respondents. The second rank answer is a gardener (kertész). One of the respondents explains that: "A gardener is taking care, helping, encouraging patiently the plants, just like the kindergarten teacher does to children."

The third rank is polyhistor which is also a code, among the answers, $17 \%$ of the respondents mentioned that teachers need the ability to have many different kinds of knowledge and competencies, the metaphors under this code include polyhistor (polyhistor), handyman (ezermester), octopus (polip).

Regarding the association to kindergarten (ovoda), we shall say that $31 \%$ of the responses (about the third of it) believe that it like a family. However, the most interesting yet popular association mentions kindergarten as a magical place. The code includes answers to magical castles, magical playgrounds, and places. However, it is not among the top \% association. The most interesting answer created a full three-part-set of metaphor: the child as a sheet of paper, kindergarten teacher as a painter, and the kindergarten itself as the picture.

\section{DISCUSSION}

In the analyzed data, we can see that there are similarities between Hungarian and Malay responses. Regarding the stimuli child Hungarian \#1 flower, \#4 clean paper while Malay answers \#1 white cloth, \#4 flowers are in the opposite order. Clean paper and white cloth as source domain of the metaphor: both are related to purity, innocence, as regarding the Malay data we mentioned the Islamic base of the metaphor, the Hungarian might followed John Lock' tabula rasa' conception, in both cases, newborn children are believed to see as clean boards, sheets, papers or cloths, need to be formed, written on by the caregivers.

In the meantime, Lao respondents seem to focus on describing the child by her/his personality, age, year. Regarding the \#5 of the Lao data, respondents seem to think of problematic children as creating the crisis.

As analyzing the kindergarten teacher stimuli, we notice one connection between the three groups; however, the ranking is different. All groups (Lao, Malay, Hungarian) mentioned the mother as the metaphor of a kindergarten teacher. The ranking is the following: \# 1 Hungarian, \#2 Malay, \#5 Lao. Another identity is taken care which is \#3 and \#4 in the Lao data with a different aspect of taking care and \#4 in the Hungarian one.

As seeing the responses of Lao teachers, they might see themselves as teachers, helpers of the children, while Malay ones loving, kind and, wise caregivers, Hungarians as motherlike gardeners, who are polyhistors and wizards.

About the kindergarten Lao respondents pointing out the place as a \#1 child, \#2 learn \#3 education, \#4 place, \#5 institutions. Does it mean that teachers are focusing on these elements, child-centred education and learning-focused places, institutions? About the Malay data the results are: \#1learning \#2fun \#3 garden \#4 play \#5 home. Learning through fun ways and incorporating play in a homely garden? However, learning is common, and the Lao institution seems to be more focused on educating the child, while the Malay one is learning through play. And last but not least the Hungarian ones: \#1family \#2 garden \#3magical place \#4home \#5nest. It seems like a garden or magical place, with a family-like homely atmosphere, helping children as a nest. 


\section{CONCLUSION}

If we try to summarize the data, we can create three kinds of narratives of childhood. First, while analyzing Lao responses, we can derive a childhood as an education-centred time, struggling with problems that teachers can help solve by being a reliable caregiver. Second, Malay construction sees them as pure, innocent creatures who need to learn through fun activities and play. Finally, the Hungarian childhood narrative of the kindergarten teachers focuses on a home and secure seeking yet growing and innocent person who needs magic.

\section{IMPLICATIONS FOR FUTURE RESEARCH}

When thinking about the limitations of the present research, we should consider the relatively small amount of the data as compared to the number of kindergarten teachers in each country with Hungary: 31.000 (KSH, 2021), Laos: 12.300 (Lao Statistics Bureau, 2021), Malaysia: 229.217 (DOSM Department of Statistics Malaysia, 2016a, b), it is not representative research in the country context. The results are valid on the examined data only. By bringing this research up, we can create hypotheses. We should consider that a kindergarten teacher's childhood narratives might depend on their studies, beliefs and the education system's core ideas.

Conflict of interest: The authors declare no conflict of interest.

Funding information: The study was funded by the Russian Foundation for Basic Research (RFBR), project № 18-512-23004.

\section{ABOUT THE AUTHORS}

Orsolya Endrődy-Nagy (PhD), is an Associate Professor at Eötvös Loránd University, Budapest, Hungary at the Department of Intercultural Psychology (Faculty of Pedagogy and Psychology). Her research interest is early years, iconography, childhood studies and cross-cultural comparative analysis. She is Editor of Hungarian Educational Research Journal and of Gyermeknevelés. Her first monography was published in 2015 by Eötvös Publishing with the title Conceptions of Childhood in the Renaissance - an Iconographic Analysis. Among her publications several are about Narratives of Childhood in Japan and Hungary.

Bahbibi Rahmatullah (PhD) is currently an Associate Professor in the Department of Computing, Faculty of Arts, Computing and Creative Industry, Sultan Idris Education University, Malaysia. Having received a BEng (Electrical) from Vanderbilt University, USA, a MEngSc from Multimedia University, Malaysia and DPhil in Eng. Science from University of Oxford, UK, she is keen in applying the technical and research skills gained in improving the quality of research and education in Malaysia. She has authored a wide range of publications and had been invited to review articles for high impact journals and conferences. Current research interest includes Child Development, Education, Information and Communication Technology (ICT), Pattern Recognition and Learning Analytics 
Istvan Lenart (PhD) is an Associate Professor at the Institute of Linguistics and Intercultural Communication at Sechenov University, Moscow. His research interests include psycholinguistics, word associations, the lacuna theory, intercultural business communication and corpus linguistics. He authored several research papers, among others, Differences of kindergarten children's linguistic picture of the world: focus on Hungary, Russia, and Laos, published in Heliyon and co-authored with Irina Markovina the paper Cross-cultural investigation of the concept of business: A new step in the development of the Lacuna Theory, appeared in the Journal of Psycholinguistics. Email: istvan.lenart@1msmu.ru.

\section{REFERENCES}

Aggné Pirka, V., \& Endrődy-Nagy, O. (2015). A 20-21. század fordulójának gyermekképe a tanítók szemszögéböl. In T. Péter, H. Ildikó, \& T. Zita (szerk.), Pedagógusok, tanulók, iskolák - az értékformálás, az értékközvetités és az értékteremtés világa: tartalmi összefoglalók: XV. Országos Neveléstudományi Konferencia (p. 214). Budapest: Óbudai Egyetem.

Aggné Pirka, V., \& Endrődy-Nagy, O. (2017a). Vélekedések a nevelésről és a nevelhetőségről óvodapedagógusok körében. (1. rész). Óvodai Nevelés, 2017(8), 16-17.

Aggné Pirka, V., \& Endrődy-Nagy, O. (2017b). Vélekedések a nevelésről és a nevelhetőségről óvodapedagógusok körében. (2. rész). Óvodai Nevelés, 2017(9), 28-30.

Ariès, P. (1960). L'Enfant et la vie familiale. Paris: Librarie Plon.

C. Jenks (Ed), (1982). The Sociology of childhood: essential readings. London: Batsford Academic and Educational.

Correia, N., Camilo, C., Aguiar, C., \& Amaro, F. (2019). Children's right to participate in early childhood education settings: A systematic review. Children and Youth Services Review, 100, 76-88. https://doi. org/10.1016/j.childyouth.2019.02.031.

DOSM Department of Statistics Malaysia (2016a). Bilangan guru di sekolah rendah dan menengah kerajaan \& bantuan kerajaan mengikut negeri dan jantina, Malaysia. Retrieved June 10, 2021, from Malaysian Social Statistics System website https://mysocialstats.stats.gov.my/report/index? topicId $=$ all\&page $=1$.

DOSM Department of Statistics Malaysia (2016b). Bilangan tadika, guru dan pelajar mengikut agensi pendidikan lain dan jantina, Malaysia. Retrieved June 10, 2021, from Malaysian Social Statistics System website https://mysocialstats.stats.gov.my/report/index?topicId=all\#.

Endrődy-Nagy, O. (2013). Óvodapedagógus-hallgatók gyermekképe és értékrendje. In K. Rózsa (szerk.), Hidak és párhuzamok a 175 éves közép-európai és magyarországi óvóképzés történetében (pp. 253-265). Szekszárd: Pécsi Tudományegyetem Illyés Gyula Kar.

Endrődy, O., Imai, R., \& Lénárt, I. (2019). Óvodások gyermekfogalma. In V. Aranka, A. Helga, \& M.-K. Zsófia (szerk.), Neveléstudomány: Horizontok és dialógusok, ÚJ KUTATÁSOK A NEVELÉSTUDOMÁNYBAN 2019. Pécs: MTA.

Endrody, O., Lenart, I., \& Markovina, I. (2020). Vállt vállnak vetve - gyerekek a gyermekkorról. Gyermeknevelés, 7(2-3), 125-135. https://gyermekneveles.elte.hu/gyn_2019-2-3_endrody-lenart-markovina_125-135.

Euridyce (2021). Compulsory education in Europe 2020/21. https://op.europa.eu/en/publication-detail/-/ publication/5a630699-1f17-11eb-b57e-01aa75ed71a1/language-en/format-PDF/source-search. 
Fives, H., \& Buehl, M. (2012). Spring cleaning for the "messy" construct of teachers' beliefs: What are they? Which have been examined? What can they tell us? https://doi.org/10.1037/13274-019.

Frickel, S., Albert, M., \& Prainsack, B. (Eds.) (2017). Investigating interdisciplinarities. New Brunswick: Rutgers.

Hendrick, H. (2000). The child as a social actor in historical sources - problems of identification and interpretation. In P. Christianssen, \& A. James (Eds), Research with children: Perspectives and practices. Oxon, Great Britain: Routledge Falmer, Taylor \& Francis Group.

Hercz, M. (2016). Narratívák, mint a pedagógusjelöltek szakmai szocializációjának indikátorai. In R. Andrea Ágnes, S. Csilla, \& T. Zsuzsa (szerk.), Távlatok a mai magyar alkalmazott nyelvészetben (pp. 88-100). Budapest: Tinta Könyvkiadó.

James, A., \& Prout, A. (1990). Constructing and reconstructing childhood: New directions in the sociological study of childhood (2nd Ed 1997 Published by Routledge ed). Oxford: Routledge. Print ISBN: 9-78075070-5967; eBook ISBN: 9-780-20336-2600.

Jenks, Ch. (2015). Constructing childhood sociologically. In J. M. Kehily (Ed.), An introduction to childhood studies. New York: Open Univerity Press.

Kementerian Pendidikan Malaysia (2013). Pelan pembangunan pendidikan Malaysia 2013-2025. PutrajayaKementerian Pendidikan Malaysia.

Kent, G. H., \& Rosanoff, A. J. (1910). A study of association in insanity. American Journal of Insanity, 67(37-96), 317-390.

Kiss, G., Armstrong, C., Milroy, R., \& Piper, J. (1973). An associative thesaurus of English and its computer analysis. In A. J. Aitken, R. W. Bailey, \& N. Hamilton-Smith (Eds.), The computer and literary studies (pp. 153-165). Edinburgh, UK: Edinburgh University Press.

KSH (2021). Központi Statisztikai Hivatal. 23.1.2.3. Az óvodások és nappali oktatásban résztvevők aránya megye és régió szerint [\%]. http://www.ksh.hu/stadat_files/okt/hu/okt0033.html.

Lachanthaboun, S. (2015). Education and Sports sector development plan 2016-2020. Ministry of Education and Sports of the Lao PDR. Vientiane. 90.

Lao Statistic Bureau (2020). Early childhood education statistics 2020. https://laosis.lsb.gov.la/ majorIndicators.do?rootId=2101000\&menuId =2101101\&paramGrpId=all\#majorIndicatorsConts [Accessed 22 Aug 2021].

Lave, J., \& Wenger, E. (1991). Situated learning: Legitimate peripheral participation. Cambridge University Press.

Lénárt, I. (2017). Associations and verbal consciousness: An analysis based on four English and one Hungarian translation of Bulgakov's novel: The master and margarita. Neohelicon, 44, 487-504. https:// doi.org/10.1007/s11059-017-0386-9.

MacKinnon, A., \& Thepphasoulithone, P. (2014). Educational Reform in Laos: A case study. International Journal of Educational Studies, 01(01), 19-34.

Majzub, R. M., \& Rashid, A. A. (2012). School readiness among preschool children. Procedia-Social and Behavioral Sciences, 46, 3524-3529.

Moss, H. E., \& Older, L. G. E. (1996). Birkbeck word association norms (1st ed.). Psychology Press. (March $1,1996)$.

Noonan, R. (2014). US aid to education in Laos, 1955-1975: A contribution to historical comparative education, embedded in time and space. Journal of International and Comparative Education, 3(1), 153-169.

OECD (2016). Education at a glance 2016: OECD indicators. Paris: OECD Publishing. http://dx.doi.org/10. 1787/eag-2016-en. 
OECD [The Organization for Economic Cooperation and Development] (2019). Providing quality early childhood education and care. OECD. https://doi.org/10.1787/301005d1-en.

ÓNOAP (2012). 363/2012. (XII. 17.) Korm. rendelet az Óvodai nevelés országos alapprogramjáról.

Palermo, D. S., \& James, J. J. (1964). Word association norms: Grade school through college. University of Minnesota Press.

Patterson, N., Doppen, F., \& Misco, T. (2012). Beyond personally responsible: A study of teacher conceptualizations of citizenship education. Education, Citizenship and Social Justice, 7, 191-206. https:// doi.org/10.1177/1746197912440856.

Permata, B. (2013). Kurikulum PERMATA Negara: Asuhan dan Didikan Awal Kanak-kanak 0-4 Tahun Cetakan Ketiga. Bahagian Pendidikan Awal Kanak-kanak Jabatan Perdana Menteri Malaysia.

Postman, L., \& Keppel, G. (Eds.) (1970). Norms of word association. New York: Academic Press.

Qin, T. Y., \& Nor, M. M. (2018). Exploring issues on teaching and learning in Malaysian Private Preschools. MOJEM: Malaysian Online Journal of Educational Management, 6(2), 67-82.

Rónay, Z. (2019). A hazai tanügyigazgatás jogszabályi keretei. Educatio, 28(2), 228-239. https://doi.org/10. 1556/2063.28.2019.2.2.

Serfözö, M, \& Böddi, Z (2018). A „hópehely” és a „varázsló” - kisgyermeknevelö-, óvodapedagógus- és tanítójelöltek szerepértelmezése. In O. Endrődy-Nagy, \& A. Fehérvári (szerk.), Innováció, Kutatás, Pedagógusok, HERA ÉVKÖNYVEK, V. (pp. 281-297). Budapest: Debrecen.

Sigel, I. E., McGillicuddy-DeLisi, A. V., \& Goodnow, J. J. (2014). Parental belief systems: The psychological consequences for children. Psychology Press.

Somsanith, P., \& Noonan, R. (2020). Preschool and primary education. In R. Noonan (Ed.), Education in the Lao People's democratic republic on track for the twenty-first century. Education in the Asia-Pacific region: issues, concerns and Prospects 51 (pp. 75-86). Singapore: Springier. https://doi.org/10.1007/978981-15-3319-8_3.

Tarasov, E. (1996). Mezkulturnoye obshcheniye - novaya ontologiya analiza yazikovogo soznaniya [Intercultural communication: New ontology of verbal consciousness analysis]. Etnokulturnaya spetsifika yazikovogo soznaniya (pp. 7-22). Moscow: Russian Academy of Science Institute of Linguistics.

Tobin, J., Hsuei, Y., \& Karasawa, M. (2009). Preschool in Three Cultures Revisited: China, Japan, and the United States. Chicago: The University of Chicago Press.

Trentinné Benkö, É. (2013, 2015). A korai kétnyelvüség támogatására szolgáló pedagóguskompetenciák és pedagógusképzés - Doktori disszertáció. Budapest: Eötvös kiadó - TEPA könyvek.

Ufimtseva, N. (2014). The associative dictionary as a model of the linguistic picture of the world. Procedia: Social and Behavioral Sciences, 154, 36-43.

Wood, E. A. (2014). Free choice and free play in early childhood education: Troubling the discourse. International Journal of Early Years Education, 22(1), 4-18. https://doi.org/10.1080/09669760.2013. 830562.

World Bank (2019). https://data.worldbank.org/indicator. Data retrieved 19 May 2021.

Open Access. This is an open-access article distributed under the terms of the Creative Commons Attribution 4.0 International License (https://creativecommons.org/licenses/by/4.0/), which permits unrestricted use, distribution, and reproduction in any medium, provided the original author and source are credited, a link to the CC License is provided, and changes - if any - are indicated. (SID_1) 